\title{
Interventions, Entrepreneurial Orientation and Macro Environment: Effect on Beneficiary Poverty Reduction by Faith Based Enterprises
}

\author{
Nalyanya N. Charles, PhD candidate, \\ Bitange Ndemo, PhD, Professor of Entrepreneurship, \\ School of Business, University of Nairobi, Kenya \\ James M. Gathungu, PhD, \\ Senior Lecturer Strategy and Entrepreneurship, \\ School of Business, University of Nairobi, Kenya \\ Ganesh P. Pokhariyal, PhD, DSc. \\ Professor of Applied Mathematics, \\ School of Mathematics, University of Nairobi, Kenya
}

Doi:10.19044/esj.2020.v16n7p157～ＵRL:http://dx.doi.org/10.19044/esj.2020.v16n7p157

\begin{abstract}
This study focuses on joint effect of interventions, entrepreneurial orientation and macro environment on beneficiary poverty reduction (BPR) by Faith based enterprises (FBEs) within the slums of Nairobi, Kenya. In Nairobi, about $60-70 \%$ of the people live in slums and conditions are deplorable. Hence, FBEs assist meet the social welfare voids like shelter, water, health services, education and employment. However, there is distorted and incomplete information with divergent views to explain success or failure of joint effects in BPR. Hinged on these gaps, the study objective of joint effect of the variables on BPR is assessed and its hypothesis is tested. The study uses a census approach and data was collected from 72 FBEs using a structured questionnaire. The study uses the descriptive cross-sectional research design and data is analysed using descriptive statistics and hierarchical multiple regression analysis. Study found that joint effect of the variables has a greater effect on BPR than the singular effect of each variable; most people in Nairobi slums live below World Bank poverty threshold of $\$ 1.90$ per day and FBEs bring disruptions that create wealth enabling people take charge of their own destinies as they escape from poverty. Key hindrances to BPR in the slums of Nairobi include lack of markets, reduced donor funding, basic needs such as food, water, shelter, health services, public schools, latrines for safe hygiene and unemployment. Study adds value to theory as findings show net works trigger the mobilization of resources which
\end{abstract}


explains robust joint effects in BPR. Adds value to human capital theory as findings reveal enterprises can deliver in social value based on relationships and doing things differently by those involved despite their illiteracy and inexperience. The paper concludes findings inform new thinking that authorities and development partners may emulate in building new funding outfits for poverty reduction such as collaborations to mobilize resources, enterprise culture for business approaches, technology for markets, quality products, politics for laws and support. Pentecostalism and Catholicism are the most prevalent in BPR within slums of Nairobi. Future research could use grounded theory approach for more in-depth investigation.

Keywords: Beneficiary poverty reduction, Faith based enterprise, Slum, Social entrepreneurship

\section{Introduction}

In recent times, there has been increased interest in Faith based enterprises (FBEs) due to need for solutions to social and economic challenges facing society. Worldwide, Faith based enterprises (FBEs) assist bring social transformations to communities in deplorable conditions with provisions for clean water, food, credit facilities, trainings, health services, path roads, and shelter amongst others (Ochanda, 2012; Deacon, 2012; Bovaird, 2006).In Kenya, it is estimated that $60-70 \%$ of people in Nairobi live in slums under deplorable conditions (APHRC, 2014). In essence, Kenya government alone is not able to manage the explosive rise in slum poverty. DePriest, \& Jones, (1997) posit due to the shortfalls in state resources, Faith based enterprises come in to assist in providing solutions to the social welfare deprivations for improved living standards. However, despite these noble efforts, the joint effect of the constructs of interventions, entrepreneurial orientation (EO) and macro environment (ME) on beneficiary poverty reduction by Faith based enterprises lack clarity as information from theory and past studies is distorted and incomplete with scholars fronting divergent views thus this paper investigation. For instance, Bokea et al, (2000), Krueger, Reilly and Carsrud (2000) posit enterprise interventions through networking mobilize macro environment resources and entrepreneurial orientation dimensions guides management teams make decisions for delivery in social value.

This perceived trajectories lead to FBEs entrepreneurial initiatives such as startups, loans, markets, shelter, health services and trainings for solutions to social and economic challenges facing beneficiaries. Haugh (2007) asserts that Faith based enterprises through congregational networks are able to draw on human or financial resources unavailable to competitors and improve lives of the disadvantaged. This concurs Ndemo (2006) posit that FBEs mobilize resources from members through local congregational 
networks to provide health care to the poor of Korogocho and Kibera slums in Nairobi. Conversely, Berger (2003) asserts FBEs exploit macro environment resources through networks to generate social, financial, cultural and spiritual capital for beneficiary poverty reduction delivery. Marris and Somerset (1971) found that enterprise intervention singly through trainings is useful to enhance acquisition of skills for employment and mobilization of resources for beneficiaries to reduce poverty.

This study is anchored on several theoretical underpinnings relevant to guide investigation on the joint effect of interventions, entrepreneurial orientation and macro environment on beneficiary poverty reduction by FBEs. The theories include networks as the major theory for mobilization of resources and other capacities, Peredo and Chrisman (2006); human capital theory (Mair\& Marti, 2006) for education and experience to promote entrepreneurship and innovations Talegata (2014); Drucker, (1985) for more gains through disruptions. The turbulent business environment and competition entail enterprises to put great emphasis on innovation for greater performance in social value delivery (Deshati, 2016; Jabeen \& Mohamood, 2014).

Deacon, (2012); Nzamujo, (2000) posit beneficiary poverty reduction is for change to stakeholder happy lifestyles, better healthy services and for a living discourse palatable to those who live in steady environments. In effect, beneficiary poverty reduction concept by FBEs is for finding solutions to social and economic problems facing the society to sustainable livelihoods and development. Outcomes of end processes in beneficiary poverty reduction include confidence building, self reliance and skills for economic growth of the disadvantaged areas like the slums (Nzamujo, 2000).

A slum as defined by the United Nations Human Settlements Programme (UNCHS) (2003) is an area that has inadequate reach to safe water; inadequate access to sanitation, infrastructure, poor structural quality of housing; overcrowded and insecure residential status. In Kenya, a slum is seen as an economically distressed marginalized area inhabited by the poor with deprivations in survival needs and has deplorable conditions that portray worst-case poverty scenarios seen. Empirical study by Zwanenberg (2008) posits that fertile grounds to the growth of poverty leading to the mushrooming of slums in Nairobi include inconsistencies in planning, failed housing and health plans, political indoctrinations, social exclusions and influx of migrants from rural areas in search of employment.

\section{Literature Review}

\section{Theory and empirical review}

The concept of Social Network theory is relevant to this study as it explains how social enterprises relate to the Macro environment to acquire 
resources for social value (Bates, 1997).According to Johannison \& Monsted (1997), Aldrich \& Zimmer, (1986) stronger networks facilitate resources for business incomes to reduce poverty. Schnell, Greenberg, Arnold and Shamai (2015) posit that social enterprises utilize social networks to exploit macro environment resources for delivery in social value. According to Gupta and Batra (2015), Lumpkin and Dess (1996), management teams utilize entrepreneurial orientation dimensions for decisions to tap Macro environment resources to facilitate delivery in social value. For clarity, Reynolds (1991) identified that social networks and macro environment contexts are catalysts for accumulating resources that promote enterprise business to excel. The Faith based organizations grassroots network assist members of same faith mobilize resources for development in their respective areas (Berger, 2003). Further, (FAO) Food and Agriculture Organization of the United Nations (2000) identifies that FBEs networks are useful ladder to help unemployed congregation members increase agricultural production through food projects and small enterprises for incomes.

Human capital theory (Mair \& Marti, 2006) fronts that education and experience is for employment and business management. The theory is relevant to this study as it guides FBEs capacity building to harness the right skills, talents and knowledge in the management teams and beneficiaries for effective delivery of social value. Haugh (2007) contends that non -profit enterprises can tap on macro environment for human resources such as experienced volunteers from the congregation to collect tithes and offerings for development to deliver social value. Shane \& Venkataraman, 2000; Becker, 1975 Anderson and Miller (2003) contend that education relationships can directly enable stakeholders discover and exploit opportunities for incomes to reduce poverty. Additionally, Gartner, (1988), Resatch and Faisst (2003) argue that experience is necessary in business as it sharpens entrepreneurs' skills to reduce business failures. Krueger et al. (2000) assert that experience and education is linked to EO dimensions of innovativeness, proactiveness and risk taking on intervention decisions for enterprise to deliver in social value.

The innovations theory advances for new creative ideas (Drucker, 1985). The theory is relevant to this study as FBEs have to adopt innovative ways to access funding, markets, suppliers, buyers, competitors and new products and services such as health care. Researchers have canvassed that the turbulent business environment and the resultant competition entail enterprises to put great emphasis on innovation for robust performance in social value delivery (Deshati, 2016; Jabeen \& Mohamood, 2014). Talegata (2014), Rauch, Wiklund, Frese and Lumpkin, (2009) argue that enterprises practice social innovation and take risks to remain relevant in a competitive environment. This approach grabs great interests as Lumpkin \& Dess, (2016); 
Kropp, Lindsay and Shoham (2006) Chen and Hambrick (1995); Drucker (1985) vouch for novelty as key for relevance of enterprise delivery in competitive business environments.

Haugh (2007); Alvarez \& Busenitz, (2001)fronts that FBE interventions are mitigations to pursue social, environmental and economic aims with religious motives for better standards of living to beneficiaries. Interventions are relevant to this study as it enables exploitation of opportunities for resources to meet social and economic problems affecting beneficiaries. Nzamujo (2000) identifies outcomes of interventions by nonprofit enterprise to include confidence building, self-reliance, economic empowerment and member responsibility. Correspondingly, Bruyat and Julien (2000) explain that FBEs interventions are integral processes for creation of new value and social change to improve living standards. The processes range from net working for resources, trainings, survival needs such as food, water, shelter, health besides financial services, human rights relief crises, legal aid, safe neighborhoods and sustainability initiatives such as homegrown business enterprises amongst others (Tadros, 2010; Raskin, 2000; Nzamujo, 2000; Mwaisela, 2000).

At this domain, Ndemo (2006) posit that social interventions such as net working to mobilize resources by Faith based organizations are largely directed towards humanitarian assistance rather than empowering communities to become self sustaining. On the contrary, Westtall, Ramsden, and Foley, (2000) argue that interventions by FBEs are out of concerns on declining standards of living among their congregations and wish to promote positive change. Haugh (2007) describes FBEs as enterprises that pursue solutions to society social, environmental and economic needs in response to social welfare gaps. Despite these noble efforts, relationships for optimal delivery in beneficiary poverty reduction by FBEs are not clear.

Gupta and Batra (2015) contend that Entrepreneurial orientation is a multidimensional construct operationalized in terms of key dimensions of proactiveness to market opportunities, innovativeness, risk taking and competitive aggressiveness as enablers for an enterprise to deliver. In essence, these elements were found to be associated with success in a research on small tourism ventures in Israel (Lerner \& Haber 2000). Lumpkin and Dess (1996) proposed the model of entrepreneurial orientation be used to guide processes and styles enterprises use within the Macro environment to engage in entrepreneurial activities. According to Bahaw (2017), enterprises need to innovate for quality products to consumers and take risks for business survival and growth in a competitive business environment. This corroborates Deshati (2016), Martin-de Castro, Delgado-Verde, Navas-Lopez and Cruz-Gonzalez (2013), Mbizi, Thondhlana, \& Kakava (2013); Kropp, Lindsay and Shoham (2006) posits that novelty is critical to discover new markets and increase 
profits for enterprise delivery. This implies that EO elements shape the entrepreneurial intent in an enterprise and may be a key ingredient to deliver social value such as incomes from startups to reduce poverty thus its relevance to this study.

Macro environment factors that enterprises utilize to gain resources include economic, socio-cultural, political /legal and technological (Pearce; Robinson and Mital 2012). According to Kotler and Armstrong (2013), the success and relevance of any enterprise depends on how it competes in its market environment as business environment has come to be volatile, unpredictable and competitive for resources. Bagheri, (2012) contends that economic environment elements may entail markets, taxation regimes, sourcing for financiers and suppliers, taxation on products and services. In effect Deacon (2012), posit that interventions by Faith based enterprises depend on socio-cultural environment factors to optimally succeed in delivery of social value to the poor. Technology elements bring change to enterprise performance such as growth, infrastructure, markets, new quality products and services (Deshati 2016). Further, political environment is critical as it may influence laws, to build sustainable enterprises that can lead to poverty reduction such as health centers, schools, water and funding agencies (Ndemo 2006). The legal environment is necessary for the FBEs to operate within the law for example laws guiding business, environment protection and the quality of products and services (Tadros, 2010).

Walter, Aver and Ritter (2006) and Covin, et al. (2006) contend that the macro environment contingent dimensions have close essential relationships with entrepreneurial orientation (EO) and the enterprise degree of entrepreneurship is the extent it applies the dimensions. Lindley and Walker (1993) assert that Macro environment as moderator may positively or negatively affect relationships between the predictor constructs and the dependent variable (BPR). Conversely, Pearce, Robinson and Mital (2012) found that the environment as a moderator might negatively affect relationships between the predictor constructs but still its factors exhibit influence in its performance. In effect, Schulze, Sieprath and Hess (2005) found that different relationships affect performance of an enterprise to deliver in social value. Deacon (2012) and Christiansen (2008) front that macro environment based factors enable an enterprise to deliver in social value. Ayuya (2018); Wekesa (2015);Covin et al. (2006) and Walter et al., (2006) posit that combined effect of variables on performance of the enterprise is greater compared to the individual effects of the same variables. However, how the joint relationships of the constructs of interventions, entrepreneurial orientation (EO) and macro environment (ME) affect beneficiary poverty reduction by FBEs is not clear as studies reviewed display distorted and incomplete information with scholars fronting different scenarios. 


\section{Conceptual Framework}

The conceptual model for this study depicts the relationships between the research variables. The study schematic diagram (figure 1) of the conceptual framework showing expected relationship between the study variables on beneficiary poverty reduction by FBEs within the slums of Nairobi.

Figure 1: Conceptual Framework Moderating variable

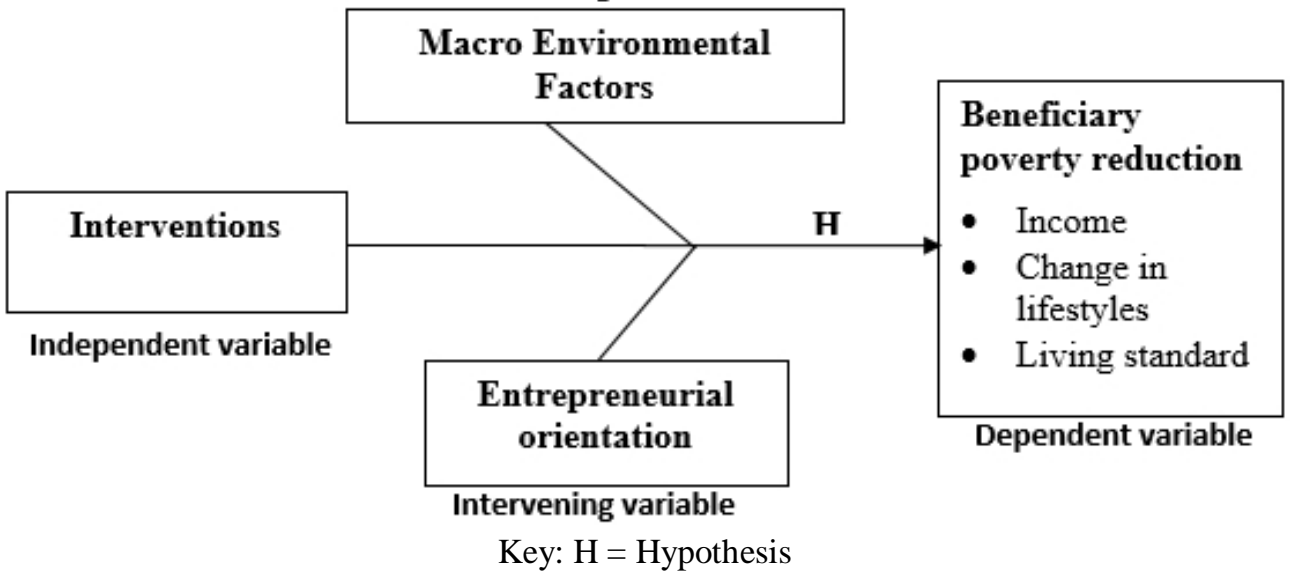

\section{Research Objective}

This paper seeks to determine the joint effect of interventions, entrepreneurial orientation and macro environment on beneficiary poverty reduction by Faith based enterprises within the slums of Nairobi, Kenya. Hence, this study tested the Hypothesis:

$\mathrm{H}$ : The joint effect of interventions, entrepreneurial orientation and macro environment on beneficiary poverty reduction within the slums of Nairobi is different from the individual effects of each variable.

\section{Research Methodology}

This study was based on positivism methodology which gives importance to research methods of cross-sectional, correlations, quantitative analysis and survey that this study adopted. The study used the descriptive cross-sectional survey research design as the objective was to determine the joint effect of the study variables relationships on beneficiary poverty reduction. According to Cooper \& Schindler, (2008), descriptive Crosssectional research design determines relationships quantitatively among variables using data gathered just once at the point of time in the survey. Different studies have used descriptive cross-sectional research design to determine relationships for instance Kerubo \& Kinoti, (2012); Bategeka, (2012), and Thuo, (2011). 
Reliability of the measurement instrument was assessed by pilot testing the questionnaire for appropriateness at 8 randomly selected FBEs in Kawangware slum. The research instrument internal consistency was also tested using Cronbach's Alpha reliability coefficient. Berthoud (2000) posits values of 0.50 and above as satisfactory for determining reliability of research instrument. The study Cronbach's Alpha coefficient test had values Interventions 0.895; Entrepreneurial orientation 0.764; Macro environment 0.845 and beneficiary poverty reduction 0.907 indicating high reliability of the instrument. The paper adopted Cronbach's Alpha coefficient cut-off of 0.7 and above. Validity of the research instrument was done by experts in Faith-based entrepreneurship pre-testing the questionnaire to ascertain its content validity. This is in line with Hair et al. (2007) posit that pre-test with sample of five to ten is adequate to validate a research instrument.This study used census method and target population comprised all 72 FBEs that were listed by the individual Faith based organizations. The FBEs listed were located in slums namely Kibera, Mukuru, Mathare, Korogocho, Huruma, Majengo Pumwani, Kariobangi, Dandora and Kangemi as follows Table 1.

Primary data was collected through structured questionnaire and secondary data was collected from FBEs reports. Drop and pick later approach was used to administer the quantitative questionnaire by trained research assistants. Two copies of the questionnaire were distributed to each of the 72 FBEs totaling 144. The two copies of the questionnaire were for two respondents from each enterprise namely beneficiary group leader and spiritual leader. The beneficiary group leader, pastor (spiritual leader) were chosen because they were likely to exhibit reliable information as they were involved in the development and actual implementation of FBE interventions for beneficiary poverty reduction. Additionally, the purpose of two respondents from each of the 72 Faith based enterprises was to enhance credibility of the data.

\section{Data Analysis}

The unit of analysis was the FBE. Data was analyzed using descriptive statistics (mean, standard deviation, coefficient of variation) and Hierarchical multiple regression analysis. The Shapiro-Wilk test reported significant values greater than 0.05 (the determinant threshold) thus evidence the data for the study was normally distributed and suitable for analysis. Levene's statistic test of Homogeneity of the Variables was significant at P-value of $0.00<0.05$. This test result ruled out Heteroscedasticity confirming the data was appropriate for further analysis.

The analytical regression model was:

$\mathrm{Y}=\alpha+\beta_{1} x_{1 a}+\beta_{2} x_{2}+\beta_{3} x_{3}+\varepsilon$ 
$\mathrm{Y}=$ Beneficiary poverty reduction

$x_{1}=$ Interventions

$x_{2}=$ Macro Environment

$x_{3}=$ Entrepreneurial orientation

$\alpha=$ constant (intercept)

$\beta=$ coefficient parameters to be determined

$\varepsilon=$ Error /disturbance

\section{Results and Discussion}

\section{Faith based enterprises distribution and Response rate}

The actual number of respondents who completed and returned the questionnaires was 115 out of the targeted 144. The study response rate was $79.9 \%$ percent.

Table 1: Response rate

\begin{tabular}{lccccc}
\hline Slum & $\begin{array}{c}\text { Number } \\
\text { of FBEs }\end{array}$ & $\begin{array}{c}\text { Questionnaire } \\
\text { Frequency }\end{array}$ & $\begin{array}{c}\text { Non } \\
\text { Response }\end{array}$ & Returned & Percentage \\
\hline Kibera & 33 & 66 & 14 & 52 & 78.7 \\
Mukuru & 17 & 34 & 8 & 26 & 76.4 \\
Mathare & 8 & 16 & 5 & 11 & 68.7 \\
Korogocho & 1 & 2 & 0 & 2 & 100 \\
Huruma & 4 & 8 & 1 & 7 & 87.5 \\
MajengoPumwani & 1 & 2 & 0 & 2 & 100 \\
Kariobangi & 3 & 6 & 0 & 6 & 100 \\
Dandora & 1 & 2 & 0 & 2 & 100 \\
Kangemi & 4 & 8 & 1 & 7 & 87.5 \\
\hline Total & $\mathbf{7 2}$ & $\mathbf{1 4 4}$ & $\mathbf{2 9}$ & $\mathbf{1 1 5}$ & $\mathbf{7 9 . 9}$ \\
\hline According & & & & & \\
\hline
\end{tabular}

According to (Graham 2002) response rate of 50\% and above is admissible to draw data analysis.

\section{Faith based enterprises and religion.}

Pentecostal FBEs capture 40.3\%, Catholic FBEs 38.9\%, Islam FBEs 9.7\%, Anglican Church of Kenya FBEs 8.3\% and Non-believers in God FBEs 2.8\%.Pentecostals and Catholics are the most prevalent within the slums. The FBEs promote services such as healthcare, education, water and shelter for better livelihoods. Pentecostalism and Catholicism are the main forces driving beneficiary poverty reduction within the slums of Nairobi. This finding corroborates Deacon (2012) that Pentecostals are major participants in poverty reduction within the slums. Wasantha (2015) contends Hinduism and Buddhism support the poor in the slums but were not covered as they were not in the population of study.

\section{Descriptive statistics for Beneficiary Poverty Reduction}

The paper investigated 28 descriptive statements on Beneficiary poverty reduction using a five point Likert type scale. The results as in Table 2. 
Table 2: Descriptive Statistics for Beneficiary Poverty Reduction

\begin{tabular}{|c|c|c|c|c|}
\hline Descriptive Statistics for Beneficiary Poverty Reduction & $\mathbf{N}$ & Mean & Std. dev & CV \% \\
\hline \multicolumn{5}{|l|}{ Income } \\
\hline Number of mobile telephone subscriptions have increased & 112 & 3.88 & 1.063 & 27.4 \\
\hline Number of business enterprises have increased & 111 & 3.77 & 1.144 & 30.4 \\
\hline There is increased number of investments & 113 & 3.71 & 1.139 & 30.7 \\
\hline There is increase in voluntary savings & 112 & 3.71 & 1.086 & 29.2 \\
\hline Number of beneficiaries with TV have increased & 113 & 3.67 & 1.176 & 32.0 \\
\hline There is increased mobilization of local resources & 112 & 3.54 & 1.056 & 29.8 \\
\hline Level of donor dependency has reduced & 113 & 3.26 & 1.469 & 45.1 \\
\hline Average daily income is less than Ksh 200 & 113 & 2.90 & 1.302 & 44.9 \\
\hline \multicolumn{5}{|l|}{ Change in Lifestyle } \\
\hline There is increased enrollment of children in formal schools & 110 & 4.21 & 0.858 & 20.4 \\
\hline There is positive attitude change towards hard work & 113 & 4.20 & 0.847 & 20.1 \\
\hline There is increased support to people living with HIV/AIDS & 112 & 4.14 & 0.929 & 22.4 \\
\hline There is increased life expectancy & 113 & 3.71 & 1.251 & 33.7 \\
\hline There is reduced rate of child mortality & 112 & 3.56 & 1.243 & 34.9 \\
\hline There are more medical centers nearby & 113 & 3.54 & 1.376 & 38.9 \\
\hline There is self-confidence and happy living & 113 & 3.48 & 1.33 & 38.2 \\
\hline There is better nutrition & 113 & 3.48 & 1.289 & 37.1 \\
\hline There is reduced crime rate & 111 & 3.47 & 1.242 & 35.8 \\
\hline \multicolumn{5}{|l|}{ Living Standard } \\
\hline More houses are connected to electricity & 112 & 3.99 & 1.027 & 25.7 \\
\hline Literacy rates increased & 112 & 3.84 & 0.945 & 24.6 \\
\hline More youth are involved in work to earn a living & 112 & 3.71 & 1.094 & 29.5 \\
\hline Live in rented iron sheet structure with cement floor & 112 & 3.63 & 1.409 & 38.9 \\
\hline Fewer people use firewood and charcoal for cooking & 112 & 3.59 & 1.346 & 37.5 \\
\hline Clean drinking water access points increased & 111 & 3.46 & 1.263 & 36.5 \\
\hline Beneficiaries have access to food throughout the week & 110 & 3.41 & 1.206 & 35.4 \\
\hline Street lights are installed and in proper working condition & 112 & 3.39 & 1.24 & 36.5 \\
\hline There are more pit latrines nearby & 111 & 3.22 & 1.358 & 42.2 \\
\hline Solid waste management centers increased & 111 & 3.05 & 1.163 & 38.2 \\
\hline Live in self-contained house & 112 & 2.06 & 1.195 & 57.9 \\
\hline Grand Mean \& Std. dev & & 3.56 & 1.180 & 34.1 \\
\hline
\end{tabular}

Note: $\mathrm{N}$ is number of observations, $\mathrm{SD}$ is standard deviation, $\mathrm{CV}$ is coefficient of variation Where $\mathrm{N}$ is below 115, it indicates that information was missing or subjects did not answer. 
Descriptive statistics findings (Table 2) provide evidence that incomes, changes in lifestyle and better living standards were key outputs of beneficiary poverty reduction by FBEs within the slums of Nairobi. The indicator for income was increase in mobile telephone subscriptions that had a mean score of 3.88 and a coefficient variation of 27.4 percent. This implies that beneficiaries have earnings thus could afford purchasing telephones. This was also an indication of improved living lifestyles reflecting reduction in poverty levels. The findings are consistent with other research posits that FBEs are engines for disruptions that create wealth and reduce poverty levels amongst Stakeholders.

Measures as to whether the number of business enterprises and investments had increased scored a mean of 3.77 and 3.71 respectively. The increase in investment means accumulation of resources thus creating more incomes for beneficiary poverty reduction.

Number of beneficiaries with TV had high mean score of 3.67 and low coefficient of variation 32.0 percent. This may imply beneficiaries had access to resources for social change. This tallies to Mwaisela (2000) that FBEs have bedrock mechanisms for distributing entrepreneurial benefits such as incomes among beneficiaries to reduce poverty levels.

The extent to which level of donor dependency reduced had a mean score of 3.26. This may mean that beneficiaries were moving towards selfreliance in resources against poverty. The high coefficient of variation 45 percent implies that donor funding is being reduced. This concurs with Bradley (2009) that aid provisions were getting lesser due to high competition and the little given comes with set conditions from donors.

The lowest mean score on income was 2.90 with a high coefficient variation of 44.9 percent. The indicator showed average daily income being less than ksh.200/- (less than $\$ 1.90$ per day). This finding indicates that majority of the FBEs beneficiaries in the slums live below the poverty line. This depicts the high poverty levels on the ground within the slums of Nairobi City County with beneficiaries suffering from divergent welfare deprivations. This is an indication that most people within the slums live below the World Bank (2016) poverty threshold of $\$ 1.90$ per day. As demonstrated here, there is need for more concerted efforts by Government and other development partners to strengthen productive activities such as seed capital for start-ups to generate incomes and assist lift beneficiaries from poverty.

The descriptive lead indicator for change in lifestyle was the increased enrolment of children in formal schools, with mean score 4.21 and low coefficient variation 20.4 percent. This finding implies that children transition across schools in the slums is doing well and accepted for acquiring skills. In the long-term, this could generate employment for incomes to reduce poverty. 
On positive attitude change towards hard work, response had a mean score of 4.20 while support to people living with HIV/AIDS recorded a mean score of 4.14. In effect, the two measures had mean above 4 and coefficient of variation between 20-22 percent. The low coefficient variation percentages and high mean indicate that hard work and support to those living with HIV/AIDS are positive attributes to enhance beneficiary poverty reduction efforts within the slums.

Extent of increased life expectancy had a response mean of 3.71 and that for reduced rate of child mortality had a mean score of 3.56.This implies that there is improved life expectancy and reduced child mortality. Existence of more medical centers had a mean of 3.54 and a coefficient variation of 38.9 percent. This implies that medical centers exist in the slums but the high variation could indicate that they are not doing well and probably do not have drugs.

Further, self-confidence and happy living had a mean of 3.48 and coefficient of variation 38 percent. The high coefficient variation may reflect that a large number of the beneficiaries may not be happy. There is better nutrition among beneficiaries as it had a mean score of 3.48. However, the high coefficient variation 37 percent could indicate not all beneficiaries have better nutrition.

The lowest score on the change of lifestyle factor was reduced crime rate with mean of 3.47 and high coefficient variation of 35.8 percent. Though low mean, finding may indicate that there is some peace contributed by FBEs. In essence, the study established Kangemi technical FBE installed free of charge solar security streetlights in Kangemi slum to promote security. The high coefficient variation of 35.8 percent may imply that security remains a problem and is not absolute within the slums. There is therefore need for FBEs to initiate collaborative efforts with government authorities for more support and protection to spur entrepreneurship for beneficiary poverty reduction within the slums.

On living standards, the descriptive finding on houses connected to electricity had a mean score of 3.99 with a low coefficient variation of 25.7 percent. This finding means that more people in the slums are now connected to electricity for daily life support such as the supply of clean running water, spray pumps for car washing and CCTV cameras for security monitoring. Increase in literacy rate had a mean of 3.84 and coefficient variation of 24.6 percent implying that many more people in the slums covered by the study could read and write. They could therefore secure employment based on the skills acquired or manage own businesses. This probably explains why more youths are involved in work to earn a living as reflected by high mean of 3.71.

Those who live in iron sheet structures with cemented floors had a mean of 3.63 and moderate coefficient variation 38.9 percent. This is an 
indication of the upward trend in the reduction of poverty as even up to the late 1990s most of the slum shanties had cow dung floors. The low use of firewood and charcoal had mean 3.59. This implies improved living standards and probably now use gas and electricity thus better lifestyles.

The statistics on access to clean water, food and availability of streetlights had high mean scores. This suggests that FBEs initiatives enable provision of water, food and streetlights and this is paramount to beneficiaries in the reduction of poverty within the slums. This corroborates FAO (2000) that FBEs enable people participation for social and economic empowerment using the congregational social networks to reduce poverty.

Extent of having more pit latrines had mean of 3.22 with high coefficient variation of 42 percent. This indicates that there are pit latrines but high coefficient variation may imply they are not adequate. Solid waste management centers increase had a moderate mean score of 3.05 and high coefficient variation of 38.2 percent. The high coefficient of variation may imply limited better hygiene and slum society may be prone to diseases. Beneficiaries living in self-contained houses had a mean score of 2.06. This low mean is indicative of serious infrastructure problems that militate against people within the slums.

Additionally, the low mean 2.06 on self-contained houses is an indicator that most of the beneficiaries still live in shanties with risks of fire outbreaks. The high coefficient variation of 57.9 percent on self-contained houses may imply that the housing sector is not doing well and beneficiaries cannot afford better housing. This means that proper shelter is lacking in the slums There is need for authorities to support communities in Nairobi slums have shelter for improved livelihoods. This paper concludes that the above crucial factors examined exhibit joint constructive synergies to explain beneficiary poverty reduction within the slum of Nairobi.

\section{The Joint Effect of Entrepreneurial Orientation, Macro Environment on} the Relationship between Interventions and Beneficiary Poverty Reduction by Faith Based Enterprises within the Slums of Nairobi, Kenya

An analysis was carried out to determine the joint effect of entrepreneurial orientation (EO), interventions and macro environment (ME) on beneficiary poverty reduction (BPR) by Faith based enterprises (FBEs) within the slums of Nairobi. Interventions were conceptualized as the Independent variable while EO was the intervening variable. The ME was conceptualized as the moderating variable and BPR by FBEs was the dependent variable. Hierarchical multiple regression analysis was done to test Hypothesis that the joint effect of interventions, entrepreneurial orientation and macro environment on beneficiary poverty reduction within the slums of 
Nairobi is different from the individual effects of each variable. The result of analysis follows Table 3.

Table 3: Joint Effect of Entrepreneurial Orientation and Macro Environment on the

Relationship between Interventions and Beneficiary Poverty Reduction

\begin{tabular}{|c|c|c|c|c|c|c|c|c|c|c|}
\hline \multicolumn{11}{|c|}{ Model Summary $^{d}$} \\
\hline \multirow[t]{2}{*}{ Model } & \multirow[t]{2}{*}{$\mathrm{R}$} & \multirow{2}{*}{$\begin{array}{c}\mathrm{R} \\
\text { Square }\end{array}$} & \multirow{2}{*}{$\begin{array}{l}\text { Adjusted } \\
\text { R Square }\end{array}$} & \multirow{2}{*}{$\begin{array}{c}\text { Std. } \\
\text { Error of } \\
\text { the } \\
\text { Estimate }\end{array}$} & \multicolumn{5}{|c|}{ Change Statistics } & \multirow{2}{*}{$\begin{array}{l}\text { Durbin- } \\
\text { Watson }\end{array}$} \\
\hline & & & & & $\begin{array}{c}\mathrm{R} \\
\text { Square } \\
\text { Change }\end{array}$ & $\begin{array}{c}\mathrm{F} \\
\text { Change }\end{array}$ & df1 & $\begin{array}{r}\mathrm{S} \\
\mathrm{C}\end{array}$ & $\begin{array}{c}\text { Sig. F } \\
\text { Change }\end{array}$ & \\
\hline 1 & $.472^{\mathrm{a}}$ & .223 & .213 & 2.88139 & .223 & 22.057 & 1 & 77 & .000 & \\
\hline 2 & $.619^{b}$ & .383 & .366 & 2.58454 & .160 & 19.704 & 1 & 76 & .000 & \\
\hline 3 & $.750^{\mathrm{c}}$ & .563 & .545 & 2.18976 & .180 & 30.873 & 1 & 75 & .000 & 1.313 \\
\hline \multicolumn{11}{|c|}{ ANOVA $^{\mathrm{a}}$} \\
\hline \multicolumn{4}{|c|}{ Model } & \begin{tabular}{l|} 
Sum of \\
Squares
\end{tabular} & Df & $\begin{array}{l}\text { Mean } \\
\text { Square }\end{array}$ & & \multicolumn{2}{|l|}{$\mathrm{F}$} & Sig. \\
\hline \multirow[t]{3}{*}{1} & \multicolumn{2}{|l|}{ Regression } & & 183.131 & 1 & 183.131 & \multicolumn{3}{|c|}{22.057} & $.000^{\mathrm{b}}$ \\
\hline & \multicolumn{2}{|l|}{ Residual } & & 639.286 & 77 & 8.302 & & & & \\
\hline & \multicolumn{2}{|l|}{ Total } & & 822.417 & 78 & \multirow[b]{2}{*}{157.375} & \multirow{2}{*}{\multicolumn{3}{|c|}{23.560}} & \\
\hline 2 & Regression & & & 314.750 & 2 & & & & & $.000^{\mathrm{c}}$ \\
\hline & Residual & & & 507.667 & 76 & 6.68 & & & & \\
\hline & Total & & & 822.417 & 78 & & & & & \\
\hline 3 & Regression & & & 462.787 & 3 & 154.26 & & 32.171 & & $.000^{\mathrm{d}}$ \\
\hline & Residual & & & 359.629 & 75 & 4.79 & & & & \\
\hline & Total & & & 822.417 & 78 & & & & & \\
\hline & & & & Coe & ficients $^{\mathrm{a}}$ & & & & & \\
\hline & Mo & & & $\begin{array}{r}\text { Unstan } \\
\text { Coeff }\end{array}$ & $\begin{array}{l}\text { ardized } \\
\text { cients }\end{array}$ & $\begin{array}{l}\text { Stand } \\
\text { Coeff }\end{array}$ & $\begin{array}{l}\text { ardized } \\
\text { icients }\end{array}$ & $\mathrm{t}$ & & Sig. \\
\hline & & & & \begin{tabular}{l|l}
$\mathrm{B}$ \\
\end{tabular} & Std. Error & & eta & & & \\
\hline 1 & 'onstant) & & & 8.535 & 2.011 & & & & 245 & .000 \\
\hline $\mathrm{Il}$ & terventions & & & .533 & .113 & & .472 & & 697 & .000 \\
\hline 2 & onstant) & & & 6.192 & 1.879 & & & & 295 & .001 \\
\hline & terventions & & & .088 & .143 & & .078 & & 613 & .541 \\
\hline & itrepreneur & al orienta & & .556 & .125 & & .562 & & 439 & .000 \\
\hline 3 & onstant) & & & 2.130 & 1.752 & & & & 216 & .228 \\
\hline & terventions & & & -.107 & .126 & & -.095 & & 851 & .398 \\
\hline & trepreneur & al orienta & & .212 & .123 & & .215 & & 730 & .088 \\
\hline & acro enviro & iment & & .758 & .136 & & .644 & & 556 & .000 \\
\hline
\end{tabular}
a. Predictors: (Constant), Interventions
b. Predictors: (Constant), Interventions, Entrepreneurial orientation
c. Predictors: (Constant), Interventions, Entrepreneurial orientation, Macro environment
d. Dependent Variable: Beneficiary poverty reduction

The result of table 3 shows there was a strong positive correlation between the independent variables of interventions, entrepreneurial orientation (EO), macro environment (ME) and beneficiary poverty reduction (BPR) as indicated by the correlation coefficient value of .750. Results show 
that model 1 explained 22.3 percent of the variation in BPR by Faith based enterprises (FBEs) within the slums of Nairobi. This means that interventions alone, when EO was introduced in model 2 the variation increased to 38.3 percent. When ME was introduced in model 3, the variation increased to 56.3 percent. The regression equation for this relationship is as follows:

$\mathrm{BPR}=2.13-.107$ Interventions $+.212 \mathrm{EO}+.758 \mathrm{ME}$

This means that if ME was increased by 1 unit (percent) BPR would increase by .758 units (percent). Increasing EO by 1 unit (percent) would increase BPR by .212 units (percent), while increase in Interventions by 1 unit (percent) would decrease BPR by -.107 units (percent).

The overall model was significant with p-values less than 0.05 and Fstatistics of $22.057,23.560$ and 32.171 respectively demonstrating that the model was robust. However, ME had a significant relationship of .000 but the p-values for intervention is .398 and EO is .088 which means that it is not statistically significant as they were greater than 0.05. Based on these results, it can be concluded that the joint effect of interventions, EO and ME on BPR within the slums of Nairobi is different from the individual effects of each variable and study fail to reject Hypothesis.

The result of the regression analysis show jointly interventions, entrepreneurial orientation and macro environment explains $56.3 \%$ of contribution in BPR performance $\left(\mathrm{R}^{2}=.563\right)$. However, these predictor variables had different individual effects from the joint effects on BPR. Individually, interventions explained 22.3 percent change $\left(\mathrm{R}^{2}=.223\right)$ in $\mathrm{BPR}$, EO explained 16 percent $\left(\mathrm{R}^{2}\right.$ changed from .223 to .383$)$ while $\mathrm{ME}$ explained 18 percent change ( $\mathrm{R}^{2}$ changed from .383 to .563$)$. The joint results corroborate Schulze, Sieprath and Hess (2005) posits that component variables differently affect performance of an enterprise to deliver.

Explicitly, the study findings show the joint effect of interventions, entrepreneurial orientation and macro environment on beneficiary poverty reduction was greater and different from individual effects of the variables. This finding is consistent with previous studies that a combined effect of variables on performance is greater than individual effects (Wekesa, 2015; Walter, 2006). The findings corroborate Monsted (1997); Becker, 1975; Drucker, (1985) link of Network, human capital, and innovations theories this study was anchored on for competencies to deliver in social value. This trajectory implies that FBEs interventions are better implemented in synergistic relationships with models of $\mathrm{EO}$ dimensions and $\mathrm{ME}$ forces to effectively drive beneficiary poverty reduction. This may mean that different relationships jointly explain BPR within the slums of Nairobi. This concurs 
Covin et al., (2006) posit that application of joint competencies is requisite for greater delivery by an enterprise.

In effect, FBEs should put emphasis on innovation to source for synergies to remain relevant in a competitive environment and keep building up new ways to enhance BPR for better livelihoods. This is in line Bahaw (2017) Martin-de Castro et al (2013), Kropp, Lindsay and Shoham (2006) posits that innovativeness creates and sustains competitive advantages for enterprise delivery. This result is consistent with findings in previous literature that enterprise delivery is determined by a combination of factors from various constructs such that no single construct effectively influences delivery by an enterprise (Murgor, 2014; Sabana, 2014; Awino, 2011; Thompson, 1999).

Correspondingly, the significant joint competencies for a greater performance in BPR corroborate Covin et al., (2006); Walter et al., (2006) that combined different relationships account for the enterprise achievement. Likewise, Ayuya (2018), Wekesa (2015) and Sagwa (2014) found that joint effect of variables on performance of the enterprise was greater compared to the individual effects of the same variables. There is therefore need for FBEs teams to scan the environment for information to strategies that jointly maximize entrepreneurship opportunities to spur beneficiary poverty reduction within the slums of Nairobi.

One of the major handicaps to success of beneficiary poverty reduction identified by this study is lack of funding. The donor funds are dwindling and the little received comes with strings attached. This finding corroborates Bradley (2009) that donor funding to non-profit enterprises is diminishing. To diffuse dependence on donors, there is need to mobilize resources through congregational social networks. This would accumulate capital for emphasis on entrepreneurial practices such as small business with proprietorship of FBEs beneficiaries to reduce poverty. It is also recommended that beneficiaries be encouraged to join Saccos (Co-operative savings and credit societies) as practice shows it is a popular grassroots savings strategy to finance investments to reduce poverty.

\section{Implications}

The study findings highlight significant contribution to social entrepreneurship development in terms of theory, policy and management practice. In essence, the findings link results to the network theory for accumulation of resources. This adds value to social network theory as it explains why there are robust joint effects on beneficiary poverty reduction by FBEs within the slums of Nairobi. The study highlights added value to human capital theory as it demonstrates that far from its dictum for education and experience emphasis, an enterprise can deliver in social value based on 
relationships and doing things differently by those involved despite their illiteracy and inexperience.

Findings put strength on continuous social innovation for relevance such as the discovery of new markets for competitive advantages. This trajectory is an indication of new light to the innovations theory in up-scaling beneficiary poverty reduction by FBEs. Study findings reveal most of the beneficiaries lack shelter and are mainly confined to makeshift shanties. This leads to need for housing policy in line with the Kenya government housing agenda for development to put up structures in the slums complete with social amenities for better lifestyles. Equally, pit latrines and sanitation facilities are limited and need uplifts.

\section{Conclusion and Recommendations}

The study findings provide ideas to meet social and economic goals for development to reduce poverty amongst the society. The paper findings provide evidence to conclude that entrepreneurial orientation (EO) dimensions, interventions and macro environment (ME) are critical ingredients that matter for faith based enterprises (FBEs) to offer greater social value and other benefits to the disadvantaged people. This conclusion relates positively to Jabeen and Mahmood (2014) posit that embedding EO elements for decision making elicits accumulation of resources for an enterprise to deliver on targets.

The finding macro environment contributed 18 percent to beneficiary poverty reduction (BPR) is emphasis for management teams to exercise due diligence when scanning the environment for optimal exploitation of resources to enhance BPR by Faith based enterprises (FBEs).Based on these findings, this paper concludes that Faith based enterprises bring disruptions that create wealth for people improved livelihoods. FBEs bring social and economic changes that impact positively on the poor. This trajectory promotes independence of the people and enables them to take charge of their own destinies as they escape from poverty.

The study shows beneficiaries live in one of the worst-case poverty scenarios as their incomes are below World Bank poverty threshold of $\$ 1.90$ per day. This paper recommends the embedding of enterprise culture by FBEs for business approaches to create wealth. This is in line with Kelly (1991) that enterprise culture promotes business for welfare provisions through activities such as entrepreneurship, education, policies, health and social services.

Likewise, technological changes as established by this study affect the operations of FBEs in beneficiary poverty reduction. There is need for a deliberate policy to promote technological advancements for FBEs and other SMEs to revolutionize records keeping for transparency, accountability and business growth. This concept corroborates Talegata, (2014), Anderson and 
Miller (2003) posits that technology is an enabler to SMEs growth with spread of incomes to disadvantaged areas. Additionally, the study findings show that people in the slums lack proper housing and live in shanties. This paper suggests the Kenya government authorities focus on slums housing under the government Big four agenda. Focus on such a strategy may assist improve provision of shelter to the vulnerable trapped in poverty and generally attract other development partners to support poverty reduction efforts.

The study demonstrates that there are increased business entities initiated by FBEs. However, there is lack of ready markets for FBEs products such as art and crafts, weaved shoes, baskets, garments and others. This paper recommends management teams do market analysis and customer needs to just offer products and services required. This would increase incomes and plough backs for beneficiary poverty reduction by FBEs. This corresponds Mbizi (2013) posit that enterprises practice market innovation to redefine market spaces for quality products and services to thrive in a competitive business environment.

The lack of food was a problem cutting across FBEs beneficiaries within the slums. This paper recommends beneficiaries with some land plots undertake sustainable agricultural practices for food security. Such agricultural practices could include growing of vegetables and poultry keeping. This strategy is suggested as FBEs support could increase agricultural production for food security which is absent and ultimately reduce dependency on dwindling aid from donors.

The findings from the research provide evidence beneficiary poverty reduction by FBEs opens links for people previously helpless to reach economic empowerment and happy living. In effect, this study concludes FBEs collaborations to mobilize resources for beneficiary poverty reduction may be a good idea for authorities and development partners to emulate for policy. This could guide in building new funding outfits for poverty reduction. Pentecostalism and Catholicism were found to be the most prevalent in beneficiary poverty reduction within slums of Nairobi. This highlights key role religion contributes to Kenya's development. The number of FBEs forming the population of the study was limited to those within the slums of Nairobi. This was a drawback to wider investigation on the beneficiary poverty reduction phenomenon. A replication of the study could be pursued covering FBEs in slums of other major towns such as Mombasa and Kisumu or global contexts. This would widely interrogate the joint effect of the relationships for new knowledge on beneficiary poverty reduction by FBEs within the slums. The study used the descriptive cross-sectional survey design. This involved the collection of data once at a particular point which limits on time. Further research could use the grounded theory Strauss and Corbin, (1990) for in-depth insights. 


\section{References:}

1. Aldrich, H. E., \& Mindlin, S. (1978). Uncertainty and dependence: Two perspectives on environment. In L. Karpit, ed., Organization and Environment. Beverly Hills, CA: Sage.

2. Aldrich, H.E \& Zimmer (1986) "Entrepreneurship through social networks". In Donald Sextion and Raymond Smulor, ed, The Art and Science of Entrepreneurship. New York: Ballinger, 3-23

3. Alvarez, S., \&Busenitz, L. (2001), "The entrepreneurship of resource based theory", Journal of Management, 27,755-775.

4. Anderson, A. \& Miller, C. (2003). "Class matters: Human and social capital in the Entrepreneurial process" The Journal of SocioEconomics, 32, 17-36.

5. APHRC (2014). Population and health dynamics in Nairobi's informal settlements: Report of the Nairobi cross-sectional slums survey (NCCS) 2012. Nairobi APHRC.

6. Awino, Z. B. (2011). Strategic management: An empirical investigation of selected variables on firm performance: A study of supply chain management in large private manufacturing firms in Kenya. Prime Journals, 1(1):9-18.

7. Ayuya, A. M. (2018). The effect of top management team characteristics and organizational learning on the strategic choices of accredited universities in Kenya. $\mathrm{PhD}$ Thesis. University of Nairobi.

8. Bahaw, P. (2017). Innovation Implementation by SMEs in Trinidad and Tobago. European Scientific Journal April 2017 edition Vol.13, No.10 ISSN: 1857 - 7881 (Print) e - ISSN 1857- 7431 186. doi: 10.19044/esj.2017.v13n10p186 URL:http://dx.doi.org/10.19044/esj.2017.v13n10p186

9. Bategeka, L. K. (2012). The Effect of Selected Firm Factors on Export of Small and Medium Manufacturing Firms in Uganda. Ph.D Thesis. Nairobi: University of Nairobi.

10. Bates, T. (1997). Financing small business creation: The case of Chinese and Korean immigrant entrepreneurs. Journal of Business Venturing, 12(2): 109-124.

11. Baumol, L. \& Schramm, C. J. (2009). Good capitalism, bad capitalism, and the economics of growth and prosperity. New Haven, CT: Yale University Press.

12. Becker, G. S. (1975). Human Capital: A theoretical and empirical analysis, with special reference to education, second edition. NBER, London: New York.

13. Berger, J. (2003). "Religious non-governmental organizations: An exploratory analysis." Voluntas: International Journal of Voluntary and Non-Profit organizations, 14 (1), 15-39. 
14. Berthoud, R. (2000). Introduction: The dynamics of social change. Bristol: Policy Press.

15. Bokea, C., Dondo, A. \&Mutiso, J. (2000). "Physical infrastructure". In Andrew Mullei and A. Bokea (eds). Micro and small enterprises in Kenya: Agenda for improving the policy environment. Nairobi: ICEG.

16. Bovaird, T. (2006). Developing new relationships with the "Market" in the procurement of public services. Public administration, 84(1), 81102.

17. Bradley, T. (2009). A call for clarification and critical analysis of the work of Faith-based development organization. Progress in Development Studies, 9(2):101-114.

18. Bruyat. C., \& Julien, P-A. (2000). Defining the field of research in entrepreneurship. Journal of Business Venturing, 16. 165-180.

19. Chen, M.J., \& Hambrick, D.C. (1995). Speed, stealth, and selective attack: How small firms differ from large firms in competitive behavior. Academy of Management Journal, 38(2):453-482.

20. Christiansen, L. (2008). Faith based social entrepreneurship. Copenhagen: Copenhagen Business School.

21. Cooper, C. R., \& Schindler, P. S. (2008). Business research methods (10th ed.). Boston: McGraw-Hill.

22. Cornwall, J. R. (1998). "Entrepreneurship in a remote sub-arctic community." Entrepreneurship Theory and Practice, 20, 57-72.

23. Covin, J. G. \& Slevein, D. P. (2006). Strategic process effects on the entrepreneurial orientation - sales growth rate relationship. Entrepreneurship Theory and Practice, 30(1) 57 - 81.

24. Deacon, G. (2012) Pentecostalism and development in Kibera informal settlement, Nairobi, Development in Practice, 22:5-6, 663674.

25. Dees, J. G. (1998). "What do you do when traditional sources of funding fall short?" Enterprising non-profits. Harvard Business Review, January-February.

26. DePriest, T., \& Jones, J. (1997). Economic deliverance through the church. Black Enterprise, 195-202.

27. Deshati, E. (2016). Business Strategies of SMEs, Innovation Types and Factors Influencing their Innovation: Albanian Case. International Journal of Economics \& Management Sciences, 5(3).

28. Drucker, P. F. (1985). Innovation and entrepreneurship. New York: Harper Publishers.

29. FAO (2000), "Peoples participation: FAO small group approach", Rural Institutions and Participation Service, Rural Development Division, available at: 
www.fao.org/waicent/faoinfo/SUSTDEV/FSdirect/FBdirect/FSP006. htm

30. Gartner, W. B. (1988). "Who is an entrepreneur?" is the wrong question. American Journal of Small Business, 12(4):11-32.

31. Giddens,A.(1976), "Introduction", in Weber, M.(Ed.), The Protestant Ethic and the Spirit of Capitalism, George Allen and Unwin, London,pp.1-12.

32. Graham, H. (2002). Market Making: Internationalisation and Global Water Markets. Journal of Indexing and Metrics, 34(5): 791-807.

33. Gupta, V. K. \&Batra, S. (2015). Entrepreneurial orientation and firm performance in India SMEs: Universal and contingency perspectives. International Small Business Journal, 1-23

34. Hair, J. Money, A. Samuel, P. \& Page, M. (2007). Research methods for business. New Jersey. John Wiley \& Sons Ltd.

35. Haugh, H. (2007). Community led social venture creation. Entrepreneurship Theory and Practice, 31 (2) 161-182.

36. Jabeen, R. \& Mahmood, R. (2014). Effect of external environment on entrepreneurial orientation and business performance relationship. Social and Basic Sciences Research Review, 2(9), 394 -403.

37. Johannison, B., Monsted, M. (1997). Contextualizing entrepreneurial networking. International Studies of Management \& Organization, 27(3): 109-137.

38. Kelly, A. (1991). The enterprise culture and welfare state: Restructuring the management of the health and personal social services. In Roger Burrows, ed. Deciphering the enterprise culture: Entrepreneurship, petty capitalism and the restructuring of Britain. London: Routledge.

39. Kerubo C.O, Kinoti M. W (2012). Factors contributing towards adoption of green marketing practices in the mobile phone service providers in Kenya. DBA African Management Review,2(1).

40. Kristiansen, S., Furuholt, B., \& Wahid, F. (2003). Internet cafe entrepreneurs: Pioneers in information dissemination. International Journal of Entrepreneurship and Innovation, 4(4), 251-263

41. Kropp, F., Lindsay, N.J., \&Shoham, A.(2006)., Entrepreneurial, market, and learning orientations and international entrepreneurial business venture performance in South African enterprises, International Marketing Review, 23(5),504-523.

42. Krueger, N.F., Reilly, M.D., \&Carsrud, A.L. (2000). Competing models of entrepreneurial intentions. Journal of Business Venturing, 15: 411-432.

43. Landstrom, H. (1998). The roots of entrepreneurship research, conference proceedings, Lyon, France November 26-27. 
44. Lerner, M., \& Haber, S. (2000). Performance factors of small tourism ventures: The interface of tourism, entrepreneurship and the environment. Journal of Business Venturing, 16. 77-100.

45. Lerner, M., \& Haber, S. (2000). Performance factors of small tourism ventures: The interface of tourism, entrepreneurship and the environment. Journal of Business Venturing, 16. 77-100.

46. Lumpkin, G. T. \&Dess, G. G. (1996). Clarifying the entrepreneurial orientation construct and linking it to performance. Academy of Management Review, 21 (1) 135-172.

47. Lumpkin, G. T. \&Dess, G. G. (2016). Linking two dimensions of entrepreneurial orientation construct to performance. Journal of Business Venturing, 16,429-451.

48. Mair, J. \& Marti, I. (2006). Social entrepreneurship research a source of explanation, prediction and delight. Journal of World Business,41(1): 36- 44.

49. Marris, P., \& A. Somerset. (1971). African Businessmen: A Study of entrepreneurship and development in Kenya. London: Routledge and Kegan Paul.

50. Martín-de Castro, M., Delgado-Verde, J., Navas-López, J., \& CruzGonzález. (2013). The Moderating Role of Innovation Culture in the Relationship between Knowledge Assets and Product Innovation. Technological Forecasting and Social Change, 80(2), 351-363.

51. Mbizi, R., Thondhlana, A., \& Kakava, N. (2013). Innovation in SMEs: A review of its Role to Organisational Performance and SMEs European Scientific Journal April 2017 edition Vol.13, No.10 ISSN: 1857 - 7881 (Print) e - ISSN 1857- 7431206 Operations Sustainability. Institute of Interdisciplinary Business Research, 4(11), 50-62

52. Mugenda, O. M. \&Mugenda, A. G. (2008). Research methods: Qualitative and quantitative approaches. African Centre for Technology Studies, Nairobi, Kenya.

53. Murgor, P. K. (2014). External, firm capabilities, strategic responses and performance of large scale manufacturing firms in Kenya- $\mathrm{PhD}$ thesis University of Nairobi Business School.

54. Mwaisela, F. A. (2000). WTO and sustainable seed multiplication programmes in Tanzania. Development, 43,(2):83-87.

55. Ndemo, B. (2006). Assessing the sustainability of faith based enterprises in Kenya. International Journal of Social Economics,33 $(5 / 6): 446-462$.

56. Nzamujo, F. (2000). A new approach to sustainable livelihoods: African youth and agriculture. Development, 42 (2):64-67. 
57. Ochanda, M. R. (2012). Faith organizations and social economic welfare in Kenya. Romanian Journal for Multi-Dimensional Education ISSN: 2066-7329.

58. Peredo, A. M. \& Chrisman, J. J. (2006). Towards a theory of community-based enterprise. Academy of Management Review, 31(2): 309-328.

59. Raskin, P. D. (2000). Bending the curve: Toward global sustainability. Development, 43 (4):64-74.

60. Rauch, A., Wiklund, J., Frese, M. \& Lumpkin, T.G. (2009). Entrepreneurial orientation and business performance: An assessment of past research and suggestions for the future. Entrepreneurial Theory and Practice, 33:761-787.

61. Resatch, F. \&Faisst, U. (2003). Measuring the performance of knowledge management initiatives. Discussion Paper. W-135, Germany: University of Augsburg.

62. Reynolds, P. D. (1991). "Sociology and entrepreneurship: Concepts and contributions" Entrepreneurship, Theory and Practice, 16 (2): 47 67.

63. Sabana, B. M. (2014). Entrepreneur financial literacy, financial transaction costs and performance of micro enterprises in Nairobi city county, Kenya. PhD Thesis. University of Nairobi.

64. Sagwa, E. V. (2014). Human resource management practices and performance of firms listed on the Nairobi securities exchange. $\mathrm{PhD}$ Thesis. University of Nairobi.

65. Schnell, Izhak\& Greenberg, Zeev\&Arnon, Sara \&Shamai, Shmuel. (2015). Entrepreneurship in the periphery and local growth: the case of northern Israel. GeoJournal. 10.1007/s10708-015-9676-9

66. Schulze, B. Thielmann, B., Sieprath, S., \& Hess, T.(2005). The Bertelsmann AG: An exploratory case study on synergy management in globally acting media organization. International Journal on Media Management, 7(3-4), 138-147.

67. Shane, S. A \&Venkataraman, S. (2000). "The promise of entrepreneurship as a field of research". Academy of Management Review, 25(1):217-226.

68. Strauss, A. \& Corbin, J.M. (1990). Basics of qualitative research: Grounded theory procedures and techniques.Thousands Oaks, CA. US: Sage Publications, Inc.

69. Tadros, M. (2010). Faith based organizations and service delivery(some Gender Conundrums) United Nations Research Institute for Social Development. 
70. Talegata, S. (2014). Innovation and Barriers to Innovation: Small and Medium Enterprises in Addis Ababa. Journal of Small Business and Entrepreneurship Development, 2(1), 83-106.

71. Thompson, A. \& Gray, C. (1999). The determinants of management development in small businesses. Journal of Small Business and Enterprise Development, 6(2):113-127.

72. Thuo, J. K. (2011). Customer relationship management practices and competitiveness of commercial banks in Kenya. PhD thesis. Nairobi: University of Nairobi.

73. UNCHS (2003) Global Report on Human Settlements 2003 is available at www.unhabitat.org/grhs/2003

74. Walter, A., Aver, M. \& Ritter, T. (2006). The impact of net capabilities and entrepreneurial orientation on university spin - off performance. Journal of Business Venturing, 21 (4); 541-567.

75. Wasantha, S. (2015). Quality of life study on slum dwellers (with special reference to SriLanka). International Journal of Scientific Research and Innovative Technology, 2(3).

76. Wekesa, L. C. (2015). Entrepreneur characteristics, competitive strategy, firm level institutions and performance of small and medium enterprises of non-timber forest production in Kenya. PhD Thesis. University of Nairobi.

77. Westtall, A., Ramsden, P. and Foley, J. (2000), Micro Entrepreneurs: Creating Enterprising communities. Institute of Public Policy Research London.

78. World Bank (2015/2016) Global monitoring report-Washington DC.

79. Zikmund, W. G., Babin, B. J., Carr, J. C., \& Griffin, M. (2010). Business research methods (8th ed.). Mason, HO: Cengage Learning.

80. Zwanenberg, R. (2008). History and theory of urban poverty in Nairobi. The problem of slum development, I.D.S Discussion Paper No.139 University of Nairobi. 